\title{
University entrepreneurship education: a design thinking approach to learning
}

\author{
Gabriel Linton ${ }^{1^{*}}$ (D) and Markus Klinton ${ }^{2}$
}

\author{
* Correspondence: gabriel.linton@ \\ oru.se \\ ${ }^{1}$ Örebro University School of \\ Business, SE-701 82 Örebro, Sweden \\ Full list of author information is \\ available at the end of the article
}

\begin{abstract}
Background: Entrepreneurship has traditionally been taught from a business administration perspective, where predicting the future is central and where the world is seen as linear with known inputs and outputs. The world of entrepreneurs is a quite different, usually highly uncertain environment, and therefore requires a different type of skill set. In this paper, we conceptualize entrepreneurial learning through a method- and design-based approach and illustrate how a course can be developed and designed.

Findings: In this paper it is argued that by utilizing design thinking and a methods approach, learning from a "through" approach can be achieved. This learning is more focused on the entrepreneurial process, highlighting the role of skills and mindset. This learning approach enables student-centered learning and focus on skills more applicable to entrepreneurs. It is also argued that the entrepreneurship process is not linear; therefore, creativity is central and finding structure is an unstructured process. Design thinking emphasizes a practical approach where students step outside the classroom. This experimentation and interaction in the real world of users and customers with real feedback is important in combination with reflection exercises.

Conclusions: This paper highlights how a methods approach and entrepreneurship education with a "through" perspective can be achieved by utilizing design thinking. This is elaborated conceptually and illustrated with an example. We argue that a methods approach for teaching entrepreneurship is beneficial, where design thinking can be one valuable tool and approach for teaching entrepreneurship.
\end{abstract}

Keywords: Entrepreneurship, Entrepreneurship education, Design thinking, Iteration, Creativity

\section{Introduction}

Entrepreneurship is a messy and complex process that is not linear (Neck and Greene 2011). Educators in entrepreneurship have the task to educate students to have the skills to survive in a fast and rapidly changing environment. Nonetheless, traditional entrepreneurship courses have focused on business plan development as a planned practice (Honig 2004; Solomon 2007), and many courses are still more "about" entrepreneurship than "for" or "through" entrepreneurship (Pittaway and Edwards 2012). In addition, many courses have a focus on business planning and prediction (Daniel 2016), which can have a negative impact on students' intention of starting a venture (Carrier 2005; von Graevenitz et al. 2010).

(C) The Author(s). 2019 Open Access This article is distributed under the terms of the Creative Commons Attribution 4.0 International License (http://creativecommons.org/licenses/by/4.0/), which permits unrestricted use, distribution, and reproduction in any medium, provided you give appropriate credit to the original author(s) and the source, provide a link to the Creative Commons license, and indicate if changes were made. 
In this paper, a different approach is taken compared to the traditional way of teaching entrepreneurship and innovation, based in no small extent on design thinking and the methods approach (Neck and Greene 2011). One of the teachers (who also is one of the authors) became frustrated with the traditional entrepreneurship course which was to a large extent based on developing a business plan. The way the course was set up, the students developed different parts of the business plan over the time of the course. Quite often, it became problematic when the different parts of the plan did not fit well together, which frequently resulted in that the individual parts were forced together in the end. Students quickly had to come up with an idea and thereafter spent most of the course developing the business plan itself. To a great degree, ignoring the pre-idea stage and the actual problem-solving activity (or opportunity creation/development) was only briefly covered, which seems common in entrepreneurship courses (Daniel 2016). During the development of the business plan, the students frequently found that the parts did not fit together, which often happened too late for real change to be possible within the time frame of the course.

It was realized that, rather than a course in entrepreneurship, the course was trying to teach small parts of all aspects of running a business (marketing, management, accounting, etc.) into one course where planning and predictability were emphasized. But, entrepreneurship is a complex process that lacks linearity of business thinking and entrepreneurship students need to master uncertain environments (Neck and Greene 2011). Hence, the business plan might not be the best tool for students studying entrepreneurship and innovation practices. Therefore, the purpose of this paper is to conceptualize entrepreneurial learning through a method- and design-based approach and to illustrate how a course can be developed and designed.

\section{Theoretical background}

\section{Entrepreneurial education}

Entrepreneurship education can be taught in different ways, and Pittaway and Edwards (2012) distinguish four different approaches to teaching entrepreneurship. They propose that the approach of teaching can be "about," "for," and "through." Most entrepreneurship education has been found to be of the "about" approach, which has a more traditional pedagogy that does not engage the students in activities and projects (Pittaway and Edwards 2012; Stovang and Nielsen 2015). We reason that entrepreneurial education should move away from approaches of "about" and "for" to be more of the character of "through." It can be argued that entrepreneurship education and learning need to reflect the process that entrepreneurs go through by focusing on action, experiences from the real world, and reflection (Kassean et al. 2015). What this entrepreneurial process consists of can be debated (Stovang and Nielsen 2015), but it can be argued that the entrepreneurial process is dominated by effectuation logics in comparison to causation logics (Sarasvathy 2001). Effectuation suggests that instead of predefining goals in highly uncertain environments, entrepreneurs rely on the means that are available at hand and co-create opportunities (Sarasvathy 2001). The effectuation logic is based on many features that align with design (Stovang and Nielsen 2015) and is closely associated with the work of Herbert Simon (1969). The opposite of effectuation is causation, which is a logic based on prediction, control, planning, and rational analysis to reach predefined outcomes (Sarasvathy 2008). 
Effectuation is also closely related to the ideas of bricolage (Baker et al. 2003; Baker and Nelson 2005) and organizational emergence (Katz and Gartner 1988). These ideas all highlight that creating entrepreneurial opportunity and developing it for the market is a process that is highly complex, social, and evolves gradually. This process is quite differentiated from a traditional manager role in an established firm where structure and predictability exist (Nielsen and Christensen 2014).

Entrepreneurship education usually has a causational approach with a focus on planning and prediction (Daniel 2016; Sarasvathy 2008). And, it has been found that many courses still use business plans as a method of teaching entrepreneurship courses (Honig 2004; Solomon 2007), which indicates that planning and predictability are in focus. Daniel (2016), p. 216) states "in a survey conducted in 2008, which encompassed 31 countries (including 27 European Union member states), it was concluded that the most common teaching method in entrepreneurship was lecturing, with some use of guest speakers (NIRAS Consultants, 2008)." It has even been found that basic courses with a focus on business plans have a negative impact on students' intentions of starting a business venture (Carrier 2005; von Graevenitz et al. 2010), which of course is not the intended outcome of most entrepreneurship courses (Liñán and Fayolle 2015). On the contrary, courses that focus on developing skills and competence show that students are more likely to start a venture (Nabi et al. 2017). As a response to the traditional entrepreneurship courses, Neck and Greene (2011) stress that entrepreneurship education should focus on how to act, anticipate, and generate in an unknown future. A possible way to do this is to take a design thinking approach (Stovang and Nielsen 2015).

\section{Design thinking}

Design thinking is essentially concerned with human needs and solving problems. Design thinking is not a strictly linear process or based on specific milestones. Rather, it is the interaction that happens between the three spaces of inspiration, ideation, and implementation (Brown and Katz 2009). The professionals of design have conventionally worked with forming, styling, designing, redesigning, and constructing artifacts, but over the past few years, the design process has become relevant for much wider use (Stovang and Nielsen 2015) such as business, innovation, and entrepreneurship. In design thinking, the problem can be seen as wicked (Buchanan 1992) because the problem is not fixed and can change and take new shapes as more is found out about the problem. The wicked problem will eventually come forward after extensive explorative activities, but even then, the problem will continue to change its face. Insights into the problem, its possible solutions, and the effects of those solutions are seen as constantly evolving (Nielsen and Christensen 2014). It has been argued that creativity and an innovative mindset is central for students in design (Koh et al. 2015). It can be reasoned that constantly challenging for new ideas and constantly rethinking current solutions are central aspects of design thinking.

\section{The new entrepreneurial education}

Neck and Greene (2011) argue that entrepreneurship is an applied discipline but is often taught as it was a natural science. They reason that entrepreneurs and designers have much in common and that entrepreneurs "think and to some extent act like 
designers" (p. 65). Conventionally, entrepreneurship education has assumed a fixed problem that can be solved through a linear problem-solving process. Also, students are often forced to come up with a business idea very quickly at the beginning of the semester and then perform planning and prediction activities with the goal of showing economic viability at the end of the course (Daniel 2016). Students of entrepreneurship courses are also often graded on the output of the course, the business plan, instead of being graded on the process of learning the skills and mindsets of entrepreneurs. Shifting focus to the process instead of the output also switches what is graded; instead of grading the business plan, the process should be graded. An effective way to capture the learning process has been through a learning log, also called a reflection log (Robinson et al. 2016).

With this in mind, there has been somewhat of a shift from the traditional courses that are more of the type "about" or ones that are "for" but have a planning approach to a more holistic approach, where the actual output from the course (e.g., business plan) is not the main goal, but developing an entrepreneurial mindset and behaviors is (Daniel 2016). The creation of new businesses is therefore not the central focus, but rather for students to develop entrepreneurial attitudes and skills (Fayolle et al. 2006). It has also been argued that entrepreneurship education should be moved away from teacher-centered to student-centered education (Daniel 2016; Robinson et al. 2016).

Neck and Greene (2011) suggest that entrepreneurship should be taught as an approach of methods instead of as a process (see Fig. 1). It has also been argued that design thinking is the possible future of entrepreneurial education (Val et al. 2017) and has many compatibilities with the methods approach (Fig. 1).

\section{The process of redesigning a course}

The following section will elaborate and illustrate how entrepreneurial education can be transformed to follow more of an approach focused on methods and developing entrepreneurial skills and mindset. Design thinking follows many aspects of the methods approach, as it is based on toolkits that usually are of a creative and iterative nature. Experimentation is a central part of design thinking, as is practice. Students that take part in a design thinking process would also develop entrepreneurial skills and techniques.

The process of redesigning the course started when the university received a grant which had the goal of increasing the entrepreneurial culture of students at the university. There was also a goal of developing entrepreneurship courses for all departments at the university. The paper describes the development of a single course over several years. The

\begin{tabular}{|cc|}
\hline $\begin{array}{c}\text { Entrepreneurship as a } \\
\text { process }\end{array}$ & $\begin{array}{c}\text { Entrepreneurship as a } \\
\text { method }\end{array}$ \\
Known inputs and outputs & A body of skills and techniques \\
Steps & Toolkit \\
Predictive & Creative \\
Linear & Iterative \\
Precision & Experimentation \\
Tested & Practiced \\
Process vs. Method approaches to teaching entrepreneurship based on Neck and Greene (2011) \\
Fig. 1 Process vs. method approaches to teaching entrepreneurship based on Neck and Greene (2011)
\end{tabular}


time periods include 3 years of experience with the "preexisting course," 1 year of development of the new course and building a "prototype course," and 2 years of running the new course. The experiences have been captured through documentation of the development process (reports for the grant, presentations of the work in progress, etc.) as well as documented learnings from the prototype courses (learning documented for each prototype). The students' perspective has also been considered from formal feedback (survey after course) and informal feedback (meetings with students), and student reflection logs have also been used to understand the students' experience. It was decided that the development process of the course should be influenced by the design process, and therefore a pilot program was first developed to allow for iteration and early feedback, instead of focusing too much on planning and predicting.

\section{First pilot}

First, a pilot program, which can be seen as a prototype, was developed and lasted for 10 weeks. The pilot was based on design thinking and centered around the "double diamond" model, which in the first diamond highlights learning about the problem and in the second diamond focuses on solutions to the problem. The pilot lasted for 10 weeks, with the 12 students alternating meeting in workshops 1 week and the next meeting with a teacher for a coaching session to help with the progress with the work in-between sessions. The problems for the pilot came from organizations that had a need to find new and innovative solutions. These organizations developed a problem statement and attended the first workshop and then were available for contact with the teams throughout the course. The organizations also attended the final workshop, where the solutions and plans forward were presented.

\section{Second pilot}

In the second pilot, some of the learnings from the first pilot related to feedback. The coaching was not only assessed as helpful but also time consuming for the teachers. In an effort to increase the teachers' effectiveness and also downplay the view that the teachers knew the right answers, the coaching part was deleted. Instead, more focus was on learning between the groups and students, with teachers as facilitators. This also resulted in a decrease in the timespan of the course from 10 weeks to 5 weeks. It was also found that the groups of students seemed to work better with four students compared to the groups with three students. A few times, a student was missing, and then the group only had two students left, which seemed to be too few to complete the workshops in a creative and energized way. In addition, although the organizations were happy with the results of the students' solutions, it was decided to keep a more "open" approach to problems without an organization behind every problem, thereby influencing the students to work in certain directions. Instead, some areas of focus where problems could be identified were compiled by the teachers before the course, and the first session included identification. These areas of problems were, for example, food waste, elder care, and segregation.

\section{Learnings from pilots}

After the second pilot, the new course was developed, based on the learnings from the pilots. Overall, the design thinking approach was received well by both the teachers 
and students. Students were found to be more engaged in developing their ideas. The focus was somewhat switched to pre-idea stages compared to only developing an idea that was not always very thought through. Several of the teams from the prototypes continued developing their ideas after the pilot was over, and one team went on to a business incubator. However, it has to be emphasized that the learning process of skills and mindset was more important than achieving great end results in the project. For the course, this resulted in clearly explaining to the students that they were not evaluated and graded on the idea itself, but rather on the process of understanding the problem and developing the idea. In the pilots, it was also found that it was important to document the process. For example, when the results from the first workshop were compared to the last workshop, the students could comprehend how much they had developed their ideas during the course.

\section{Contents of a new course}

Preparation

Teams need to be formed, and each team needs a challenge to solve. The teams should be formed with as high heterogeneity as possible, where different points of view from the students can contribute, rather than homogeneous teams that think alike. The challenges can be distributed by the teacher. We have had success with challenges that have been identified by the teachers, e.g., society-based challenges such as how to reduce food waste, and the teachers have also had success with asking different types of organizations to provide challenges they need to solve (e.g., how can customers have an improved experience while waiting in the lobby for our service?). The student groups themselves can also identify challenges: have the students ask different types of professions, e.g., a nurse or a bus driver, about common challenges they face. From our experience, it is useful for the students not to think about their own personal challenges or campus-related challenges as they themselves experience the challenge and therefore have a difficult time seeing the bigger picture and interviewing fellow classmates. It is better for the students to take on a challenge that is new to them. The challenge should specify the purpose and goal of the solution. It is a good idea to identify possible results of the solutions, but not suggest what type of solution that is needed. Also, some limitations might apply.

\section{Module 1: Discovery of challenge}

Discovery is about understanding the context of the challenge by collecting information. Here, it is emphasized that students get out of the classroom and collect data about users' experiences and people with expert knowledge about the challenge. To be able to solve the challenge, the team needs plenty of information about the challenge they are about to solve and to build empathy with the users. Often students (and we as teachers) will see one easy solution right away, but, at this stage, the focus should be on the challenge and not yet on trying to solve it.

Interviews can be a powerful tool to collect information and get a deeper understanding of the situation. First, try to identify different types of people that can share their insights. Users are of course essential; however, other people might also be able to provide useful information. For example, if you want to know more about people's preferences about food choices at a certain place, you, of course, can ask the people eating 
and serving food. However, the people that clean the area might have useful information about what type of food that they have noticed has been thrown away or left behind. Open questions are preferred which do not restrict the answers that yes and no questions usually do. Follow-up questions are also encouraged because the first answer you get might not tell the whole story. Why? When? How? What is an example of that? These can all be useful follow-up questions to dig deeper into a previous answer.

Observation is a research approach often applied in ethnography and anthropology but used more and more to understand users. Interviews can provide a rich understanding but sometimes the users themselves will not know (when asked) why they act in a certain way, and it is easy to come to premature conclusions. By observing (at least $60 \mathrm{~min}$ ) to understand users' needs and preferences in a certain situation, a deeper understanding of why people act the way they do can be achieved. During the observation, the focus should be on what is happening and which behaviors are noticed (not counting, measuring, or thinking about solutions).

\section{Module 2: Interpretation of challenge}

After module 1, the teams should have collected plenty of different types of information about the challenge. Now is the time to start to sort and analyze the information and consider the following questions: what can we learn from all of it? What are the needs of the user? When talking about needs, we emphasize not only physical needs such as that the solution is functional but also cognitive needs in the form of user-friendliness and emotional needs in the form of feeling pleasure and meaningfulness. When analyzing for needs, the teams will seek patterns, structures, and relationships that can give a deeper understanding of the needs. What are the keywords that describe the challenge? Can they be structured or sorted in a specific way?

Creating personas is a powerful method for understanding users. Who are the typical users in terms of attitudes, motivations, and goals? What is the narrative that describes how personas act in a sequence of actions? When creating a persona, it should describe the specific wants or needs of the persona. Another method is mapping the customer journey from initial contact and into a long-term relationship.

\section{Module 3: Ideation of solutions}

Once the teams have a deep understanding of the challenge, they can start to create solutions for it. Creativity is at the forefront, where the focus is on thinking differently and in new ways. In this module, there is no learning without coming up with many ideas and knowing that many of the ideas will fail. It is important to create many ideas, where some are wild and crazy. Usually, the first idea is not the best idea. We challenge the students to be creative and ask the teams to come up with at least 50 solutions to the challenge. Here, we emphasize keeping the ideas simple and not criticizing them. The method of brainstorming in different ways can be a good way to come up with many different ideas.

\section{Module 4: Prototyping of solutions}

In the prototyping module, the teams take their ideas for solutions and start sorting and grouping them to find realistic solutions. The teams then take a few ideas (3-10) 
further and prototype them. The purpose of prototyping several ideas is to advance the one-sentence statement into a more advanced solution. This can be done through a simple sketch, Legos, or perhaps an advertisement describing the main features. The teams can then go out and interview users, show them the simple prototypes, and get feedback on which ones to develop further. As the number of prototypes is reduced, the more advanced prototypes can be developed, with more detail and functionality. More advanced prototypes include functional prototypes that solve the functional challenge but do not have the final design; it can be a 3D computer simulation, a scaled-down version, and so on.

\section{Module 5: Solution and future}

In the last module, the students present their final solution and prototype(s). This can be done by pitching the solution to an audience or showcasing the prototypes in a student exhibition. In this module, the teams also develop a plan looking forward. What team members and resources are needed to complete the solution? What needs to be completed, and what would a timeline consist of?

\section{Grading and assessment}

The view that learning the entrepreneurial process is more important than the outcome (e.g., business plan) shifts what should be graded. Moving to the process, the final presentation of the idea is not graded. Instead, the focus is on the process, and the students are graded (which they document) on how they complete the different modules and what learnings they have achieved in each module. Essentially, the students document how they have completed each module and present this in their report together with the final solution. In addition, each student creates a learning log where specific questions are answered. For example, what was the greatest takeaway from developing several prototypes?

\section{Discussion}

In this entrepreneurship course, students are exposed to developing new solutions for a problem/challenge and practicing identifying entrepreneurial opportunities. The focus is also on the pre-entrepreneurial process, focusing on identifying the opportunity and developing it. Previous entrepreneurship research has to a large degree focused on the latter part of the entrepreneurial process (Kreuger and Welpe 2014), which also reflects the entrepreneurship education (Daniel 2016). The traditional entrepreneurship theory has assumed that opportunities already exist and require alertness to discover them (Kirzner 1973). The centrality of creating opportunities in entrepreneurship research has later been highlighted (Alvarez and Barney 2007), and this centrality has slowly started to shift the focus in entrepreneurial education from the planning and prediction to the pre-idea phase of creating opportunities. Connecting entrepreneurship education with design thinking and a methods approach, in line with education "through," is one way to focus more on the creation of opportunities, instead of assuming ideas exist and the entrepreneur only needs to act on them.

Previous research has highlighted the value of learning/reflection logs as an essential tool in teaching entrepreneurship (Robinson et al. 2016). Our experiment also shows that 
the students learn in an enhanced way when reflecting throughout the course on their development. The teachers have also noticed an improvement in outcome in the quality of ideas in the new course compared to the old one, even though this aspect has been deemphasized in the new course. This finding can indicate that when the students worry less about the outcome and instead focus on the process, the outcome will be of high quality anyway. The reflections also help the students connect the practical knowledge with their understanding of the theoretical perspectives of entrepreneurship. When the students look back at their early reflections, they often find that their comprehension of the challenge changes and that the most obvious solution is not always the best one.

Previous research has underlined the usefulness of design thinking for promoting entrepreneurial skills (Val et al. 2017). Our experiment with switching to a design thinking-based course as a possible new entrepreneurial education approach should be seen in many ways as a positive change. Design thinking underscores a classroom culture that fosters collaboration and creativity, which can be in contrast to traditional formal education at the university level. Iteration is an important aspect of the methods approach (Neck and Greene 2011). When opening up the course to iterations as a natural part of the entrepreneurial process, the ideas became more developed. When comparing the end results of the old course and the new course, a clear trend can be noticed, as the parts of the ideas fit together much better and the ideas were not forced together, which was one of the triggers for the teachers to redesign the course. Research on new ventures shows that ventures can learn much from these iterations in the entrepreneurial process (Hasche and Linton 2018). When focusing more on iterations, students seem to dare more to do an iteration and show that they learned something and went back and made it right, instead of covering up and making ideas of a more "make-believe" character.

Using design thinking for entrepreneurship education also shifts the center of attention away from the teacher and more to a student-centered learning (Daniel 2016; Robinson et al. 2016). The active workshops and the reflection logs help students facilitate their own learning in a much different way compared to the traditional university lecture style of learning. In agreement with Val et al. (2017) we extend the thoughts of the fit of design thinking with entrepreneurship education by illustrating an example of how a course can be modified and we also extend the theoretical arguments for why design thinking is a suitable for entrepreneurship education.

From our experience, students gain a deeper level of understanding by taking a practice approach, stepping outside the classroom and experimenting in the real world of users and customers with real feedback. Thus, the focus from the "about" and "for" approaches of entrepreneurial education has turned to a "through" approach (Pittaway and Edwards 2012). Edelman et al. (2008) suggest that more of a practice approach can help to develop an entrepreneurial skill set. We find that it is difficult to assess if the students have more or less entrepreneurial skills with the new course; however, we can note that the students leave with a different set of entrepreneurial skills that are more focused on creativity, collaboration, and problem-solving. These skills seem to include more entrepreneurship characteristics, while the previous course developed more (small) business skills.

\section{Conclusions}

The paper contributes with extending the theoretical connection between entrepreneurial education and design thinking compared to previous research in this literature 
stream (e.g., Armstrong 2016; Daniel 2016; Nielsen and Christensen 2014; Stovang and Nielsen 2015; Val et al. 2017). The paper also contributes by conceptually connecting previous research that call for both a methods approach (Neck and Greene 2011) and entrepreneurship education with a "through" perspective (Pittaway and Edwards 2012); this paper highlights how these approaches can be achieved by utilizing design thinking (Brown and Katz 2009).

\section{Acknowledgements}

We are thankful for the language editing provided by M. Comstock. We are also thankful for the insightful comments and suggestions from two reviewers and the editor which helped improve the paper.

\section{Funding}

Gabriel Linton was supported by the Faculty for Business,Science, and Technology at Örebro University.

Availability of data and materials

Does not apply

\section{Authors' contributions}

GL has been the lead author, with the main responsibility of developing the research and manuscript. MK has been involved as a co-author and contributed actively with ideas and concepts for the research and the practical implementation of the research and empirical data, and assisted in developing the short report. Both authors read and approved the final manuscript.

\section{Authors' information}

Gabriel Linton, Ph.D., works as an assistant professor at the Örebro University School of Business. His research is focused around entrepreneurship and innovation with an interest in, for example, startups, firm's entrepreneurial orientation, and regional innovation systems.

Gabriel serves as a member of the editorial review board for the Journal of Small Business and Entrepreneurship. Gabriel has previously published in journals such as Journal of Business Research, R\&D Management, European Journal of Innovation Management, and Journal of Small Business and Entrepreneurship.

Markus Klinton, Ph.D., works at the Department of External Relations at Örebro University. His research is focused around the organization of work and employment.

\section{Consent for publication}

Not applicable

\section{Competing interests}

The authors declare that they have no competing interests.

\section{Publisher's Note}

Springer Nature remains neutral with regard to jurisdictional claims in published maps and institutional affiliations.

\section{Author details}

${ }^{1}$ Örebro University School of Business, SE-701 82 Örebro, Sweden. ${ }^{2}$ Örebro University External Relations, SE-701 82 Örebro, Sweden.

Received: 29 August 2018 Accepted: 9 December 2018

Published online: 14 January 2019

\section{References}

Alvarez, S. A., \& Barney, J. B. (2007). Discovery and creation: Alternative theories of entrepreneurial action. Strategic Entrepreneurship Journal, 1(1-2), 11-26. https://doi.org/10.1002/sej.4.

Armstrong, C. E. (2016). Teaching innovation through empathy: Design thinking in the undergraduate business classroom Management Teaching Review, 1(3), 164-169. https://doi.org/10.1177/2379298116636641.

Baker, T., Miner, A. S., \& Eesley, D. T. (2003). Improvising firms: Bricolage, account giving and improvisational competencies in the founding process. Research Policy, 32(2), 255-276. https://doi.org/10.1016/S0048-7333(02)00099-9.

Baker, T., \& Nelson, R. E. (2005). Creating something from nothing: Resource construction through entrepreneurial bricolage. Administrative Science Quarterly, 50(3), 329-366. https://doi.org/10.2189/asqu.2005.50.3.329.

Brown, T., \& Katz, B. (2009). Change by design : How design thinking transforms organizations and inspires innovation. New York: Harper Business.

Buchanan, R. (1992). Wicked problems in design thinking. Design Issues, 8(2), 5-21. https://doi.org/10.2307/1511637.

Carrier, C. (2005). Pedagogical challenges in entrepreneurship education. In The dynamics of learning entrepreneurship in a cross-cultural university context (pp. 136-158).

Daniel, A. D. (2016). Fostering an entrepreneurial mindset by using a design thinking approach in entrepreneurship education. Industry and Higher Education, 30(3), 215-223. https://doi.org/10.1177/0950422216653195. 
Edelman, L. F., Manolova, T. S., \& Brush, C. G. (2008). Entrepreneurship education: Correspondence between practices of nascent entrepreneurs and textbook prescriptions for success. Academy of Management Learning \& Education, 7(1), 56-70. https://doi.org/10.5465/amle.2008.31413862.

Fayolle, A., Gailly, B., \& Lassas-Clerc, N. (2006). Assessing the impact of entrepreneurship education programmes: A new methodology. Journal of European Industrial Training, 30(9), 701-720. https://doi.org/10.1108/03090590610715022.

Hasche, N., \& Linton, G. (2018). The value of failed relationships for the development of a Medtech start-up. Journal of Small Business \& Entrepreneurship, 30(1), 97-119. https://doi.org/10.1080/08276331.2017.1388953.

Honig, B. (2004). Entrepreneurship education: Toward a model of contingency-based business planning. Academy of Management Learning \& Education, 3(3), 258-273. https://doi.org/10.5465/amle.2004.14242112.

Kassean, H., Vanevenhoven, J., Liguori, E., \& Winkel, D. E. (2015). Entrepreneurship education: A need for reflection, real-world experience and action. International Journal of Entrepreneurial Behavior \& Research, 21(5), 690-708. https://doi.org/10.1108/ IJEBR-07-2014-0123

Katz, J., \& Gartner, W. B. (1988). Properties of emerging organizations. Academy of Management Review, 13(3), 429-441. https:// doi.org/10.5465/amr.1988.4306967.

Kirzner, I. (1973). Competition and entrepreneurship. Chicago: University of Chicago Press

Koh, J. H. L., Chai, C. S., Wong, B., \& Hong, H.-Y. (2015). Design thinking and education. In J. H. L. Koh, C. S. Chai, B. Wong, \& H.-Y. Hong (Eds.), Design thinking for education: Conceptions and applications in teaching and learning (pp. 1-15). Singapore: Springer Singapore. https://doi.org/10.1007/978-981-287-444-3_1.

Kreuger, N., \& Welpe, I. (2014). Neuroentrepreneurship: What can entrepreneurship learn from neuroscience? Annals of entrepreneurship education and pedagogy 2014, 60.

Liñán, F., \& Fayolle, A. (2015). A systematic literature review on entrepreneurial intentions: Citation, thematic analyses, and research agenda. International Entrepreneurship and Management Journal, 11(4), 907-933. https://doi.org/10.1007/s11365-015-0356-5.

Nabi, G., Liñán, F., Fayolle, A., Krueger, N., \& Walmsley, A. (2017). The impact of entrepreneurship education in higher education: A systematic review and research agenda. Academy of Management Learning \& Education, 16(2), $277-299$. https://doi.org/10.5465/amle.2015.0026

Neck, H. M., \& Greene, P. G. (2011). Entrepreneurship education: Known worlds and new Frontiers. Journal of Small Business Management, 49(1), 55-70. https://doi.org/10.1111/j.1540-627X.2010.00314.x.

Nielsen, S. L., \& Christensen, P. R. (2014). The wicked problem of design management: Perspectives from the field of entrepreneurship. The Design Journal, 17(4), 560-582. https://doi.org/10.2752/175630614X14056185480113.

NIRAS Consultants, FORA and ECON Pöyry (2008) Survey of Entrepreneurship in Higher Education in Europe. Brussels: European Commission, Directorate-General for Enterprise and Industry.

Pittaway, L., \& Edwards, C. (2012). Assessment: Examining practice in entrepreneurship education. Education + Training, 54(8/ 9), 778-800. https://doi.org/10.1108/00400911211274882.

Robinson, S., Neergaard, H., Tanggaard, L., \& Krueger, N. F. (2016). New horizons in entrepreneurship education: From teacherled to student-centered learning. Education + Training, 58(7/8), 661-683. https://doi.org/10.1108/ET-03-2016-0048.

Sarasvathy, S. D. (2001). Causation and effectuation: Toward a theoretical shift from economic inevitability to entrepreneurial contingency. The Academy of Management Review, 26, 243-263.

Sarasvathy, S. D. (2008). Effectuation: elements of entrepreneurial expertise. Cheltenham: Elgar.

Simon, H. (1969), The Science of the Artificial, MIT Press, Cambridge, MA.

Solomon, G. (2007). An examination of entrepreneurship education in the United States. Journal of Small Business and Enterprise Development, 14(2), 168-182. https://doi.org/10.1108/14626000710746637.

Stovang, P., \& Nielsen, S. L. (2015). DesUni: University entrepreneurship education through design thinking. Education + Training, 57(8/9), 977-991. https://doi.org/10.1108/ET-09-2014-0121.

Val, E., Gonzalez, I., Iriarte, I., Beitia, A., Lasa, G., \& Elkoro, M. (2017). A design thinking approach to introduce entrepreneurship education in European school curricula. The Design Journal, 20(sup1), S754-S766. https://doi.org/10.1080/14606925.2017.1353022.

von Graevenitz, G., Harhoff, D., \& Weber, R. (2010). The effects of entrepreneurship education. Journal of Economic Behavior \& Organization, 76(1), 90-112. https://doi.org/10.1016/j.jebo.2010.02.015.

\section{Submit your manuscript to a SpringerOpen ${ }^{\circ}$ journal and benefit from:}

- Convenient online submission

Rigorous peer review

- Open access: articles freely available online

- High visibility within the field

Retaining the copyright to your article

Submit your next manuscript at $\boldsymbol{\nabla}$ springeropen.com 